\title{
アルカリ性垔鉊メッキにおける陽極の挙動
}

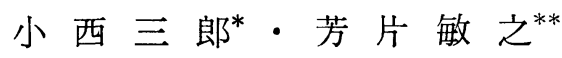

\section{Anodic Behavior of Zinc and Iron in Alkaline Zinc Plating Baths}

Bright Zinc Plating From Zincate Bath (Part 4)

Saburo KONISHI and Toshiyuki YOSHIKATA

Studies were made on anodic behavior of each or together of zinc and iron in various kinds of alkaline zinc plating baths.

The results obtained were as follows :

1) The polarization of zinc anode was decreased with the decrease in concentration of $\mathrm{OH}$ or $\mathrm{CN}$ ions and was increased with the increase in concentration of $\mathrm{Zn}$ ions in plating baths.

2) In activated state, anodic current efficiency of zinc was $100 \%$. A film corresponding to $\mathrm{Zn}(\mathrm{OH})_{2}$ grew at the potential between critical passivity and Flade ; and a film corresponding to $\mathrm{ZnO}$ grew at the potential for retaining passivity. The anodic current efficiency of zinc was decreased under these conditions. However, the current efficiency for zinc both contained in the films and dissolved was about $100 \%$.

3) When both of zinc and iron were used together for anode, only anodic behavior of zinc was indicated at the initial stage ; and then, the bath was led to potential for generating oxygen from iron when the current passed through the critical passivity of current density of zinc. At this stage, zinc anode was electrolyzed at the potential for retaining passivity.

The problems mentioned above are important in controlling of anode and plating bath in practice of alkaline zinc plating.

\section{1. まえがき}

従来までは, 光沢亜鉛メッキはシアン化亜鉛メッキ浴 からメッキされていたが，近年シアン公害の見地からシ アン化ナトリウム濃度の低い低シアン亜鉛メッキ浴, シ アンをまったく使用しないジンケート浴からの光沢亜鉛 メッキが研究され，一部で工業的に実施されている。現 在われわれるこれらの浴からの光沢亜鉛メッキについ て検討しているが, これらの浴から亜鉛メッキを行なっ た場合, 明らかに, その陽極の挙動が異なっていること に気づく。

最近では, シアン化亜鉛メッキ浴の低シアン浴ないし

† シンケート浴からの光沢亜鉛メッキの研究(第 4 報),

前報（第 3 報）：金属表面技術, 20, 315 (1969)

*大阪府立工業奖励館東大阪分館 (大阪府東大阪市高井田 中1) Industrial Research Institute Osaka Prefecture **县野製薬工業(株)(大阪府大阪市城東区放出中) Okuno Chemical Industry Co., Ltd.
ジンケート浴への転換, メッキ液または陽極亜鉛の管理 のために，亜鉛陽極の代わりに鉄陽極を使用したり，両 者を併用したり，あるいは，鉄網製のバスケットに亜鉛 陽極を入れて使用することもある。このような場合に は, その陽極の挙動をよく知っておくことが必要であ る。シアン化亜鉛メッキ浴に打いて亜鉛と鉄陽極を併用

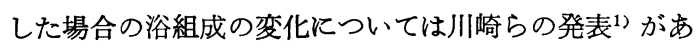
り，筆者も以前に一部を発表23,3)している。また，亜鉛 の陽極挙動については, 電池の条件として水酸化カリウ

第 1 表 使用亜鉛メッキ浴の代表的浴組成

\begin{tabular}{|c|c|c|c|c|c|c|}
\hline & \multicolumn{2}{|c|}{$\begin{array}{l}\text { シアン化賈 } \\
\text { 鉛メッキ浴 }\end{array}$} & \multicolumn{2}{|c|}{$\begin{array}{l}\text { 低シアン㶾 } \\
\text { 鉛メッキ浴 }\end{array}$} & \multicolumn{2}{|c|}{$\begin{array}{l}\text { 浴ンケート } \\
\text { 济 }\end{array}$} \\
\hline & $\mathrm{g} / l$ & $\mathrm{M} / l$ & $\mathrm{~g} / l$ & $\mathrm{M} / l$ & $\mathrm{~g} / l$ & $\mathrm{M} / l$ \\
\hline 亜 鉛 & 32 & 0.5 & 8 & 0.125 & 8 & 0.125 \\
\hline $\begin{array}{l}\text { シアン化 } \\
\text { ナトリウム }\end{array}$ & 98 & 2.0 & 9.8 & 0.2 & - & - \\
\hline $\begin{array}{l}\text { 全水酸化 } \\
\text { トリウウ }\end{array}$ & 80 & 2.0 & 8.0 & 2.0 & 80 & 2.0 \\
\hline
\end{tabular}




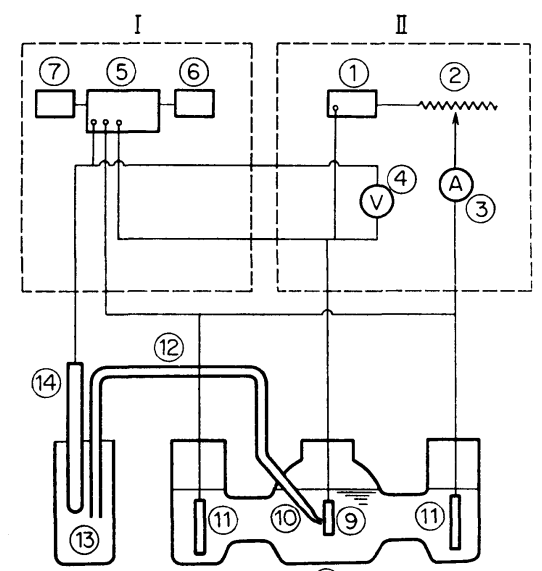

(8)

\begin{tabular}{|c|c|c|}
\hline I & 定電位電解装置 & II 定電流電解装置 \\
\hline (1) & セレン整流器 $75 \mathrm{~V}$ & (8) 電解槽 \\
\hline (2) & 高抵抗 & (9) 陽極 \\
\hline (3) & 精密電流計 & (10) キャピラリー \\
\hline (4) & 真空管単位差計 & (11) 陰極 \\
\hline (5) & ポテンショスタット & (12) 寒天ブリッシ \\
\hline (6) & レューダー & (13) 飽和塩化カリウム溶液 \\
\hline (7) & 電量計 & (14) 飽和甘コウ電極 \\
\hline
\end{tabular}

第1図 定電位および定電流電解装置

ム溶液における活性化から Flade 電位まではよく研究さ れている4),55。しかし，メッキ浴中に打ける亜鉛の陽極 挙動についてはあまり報告されていない。

そこでわれわれは, シアン化亜鉛メッキ浴, 低シアン 亜鉛メッキ浴扣よびジンケート浴などのアルカリ性亜鉛 メッキ浴中での亜鉛，鉄および両者を併用した場合の陽 極の挙動について検討した。

\section{2. 実 験 方 法}

\section{2-1 使用メッキ浴の組成と陽拯}

本実験に使用したメッキ浴は，第 1 表に示した組成を 標準とし各成分を变化した。な特，浴温は $30^{\circ} \mathrm{C}$ 一定と し，カキマゼは行なわなかった。

亜鉛陽極としては, メッキ工場で問題なく使用してい た公称 $99.99 \%$ 亜鉛陽極を $20 \times 10 \times 5 \mathrm{~mm}$ の大ささに加 エし，側面は樹脂でマスキングしたものを試料とした。 鉄陽極についても同様の大きさのものを用いた。前処理 としては，0/6エメリー 紙と酸化マグネシウムで研摩し たのち， $5 \mathrm{vol} \%$ 塩酸で活性化し，5\%水酸化ナトリウ ム溶液で中和した。

\section{2-2 分㮒の測定}

分極の測定は第 1 図に示した装置で行なった。定電位 電解による分極は, 飽和甘コウ電極を照合電極とし，柳 本製ポテンショスタット1001型, 自動印加電圧装置と記 録計 PJ-1 型を使用し， $150 \mathrm{mV} / \mathrm{min}$ で測定した。定電
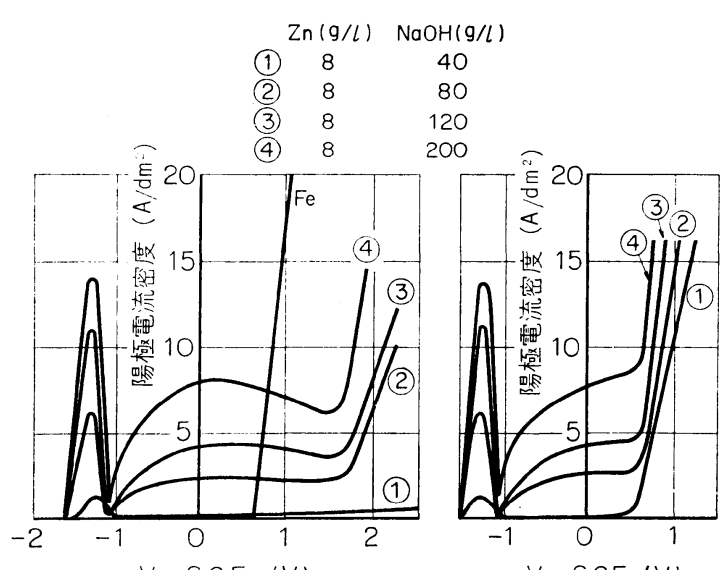

Vs. S.C.E. (V)

第 2 図 ジンケート浴での亜鉛，鉄の単独（左）およ び両者を併用した場合（右）の定電位電解に よる電流一電位曲線

流電解による分極は, 高電圧電源に高抵抗をそう入する 方法6)を用い, 電流は抵抗器で手動で規制し, 電位は横 河電機製真空管抵抗電位差計 VM51 で読み取り, 電流電位曲線を画いた。

\section{2-3 陽桱の電流効率と皮膜の分析}

通常の電解による 亜鉛陽極の 電流効率は横河電機製 EAH-11 型積算電量計を用いて，0.1 Ah に护ける陽極 覀鉛の重量減から求めた。また定電位電解に打ける電流 効率はポテンショスタットと積算電量計を組み合わせ, 各電位に打ける0.1Ah当たりの電流効率を測定した。な お，この場合に护電流効率は, メッキ液中に溶出し た亜鉛のみの効率と表面に生成した皮膜中の亜鉛を次の 方法で求めた值を加味した効率の両方について測定し た。

表面に生成した皮膜中の亜鉛の分析方法については, いろいろ検討したが次に述べる方法で行なった。すなわ ち, 皮膜が生成した亜鉛陽極を $\mathrm{pH} 9 \sim 10$ のアンモニアー 塩化アンモニウム緩衝溶液で皮膜を溶解したのち, 亜鉛 をBT指示薬を用いて 0.01M. EDTA で定量した。この 場合に使用した $\mathrm{pH} 9 \sim 10$ のアンモニア緩衝溶液は皮膜 の溶解に比べて金属亜鉛の溶解はほとんど無視できるも のであった。

\section{3. 実験結果と考察}

\section{3-1 定電位電解による電流一電位曲線}

第 2 図は，ジンケート浴に拉ける水酸化ナトリウムの 濃度変化による亜鉛, 鉄の単独执よび両者を併用した場 合の定電位電解による 電流-電位曲線の変化を示してい る。高シアンおよび低シアン浴に拈いても，これとほぼ 
$\mathrm{Zn}(9 / l) \quad \mathrm{NaCN}(\mathrm{g} / l) \quad \mathrm{Zn}(\mathrm{g} / l)$ 全 $\mathrm{NaOH}(\mathrm{g} / l) \quad \mathrm{NaCN}(\mathrm{g} / l)$ 全 $\mathrm{NaOH}(\mathrm{g} / l)$

$\begin{array}{ccccccccc}\text { (1) } & 0 & 0 & (1) & 8 & 80 & (1) & 98 & 80 \\ (2) & 8 & 9.8 & (2) & 0 & 0 & (2) & 9.8 & 80\end{array}$

(3) $32 \quad 98$

(4) $8 \quad 0$

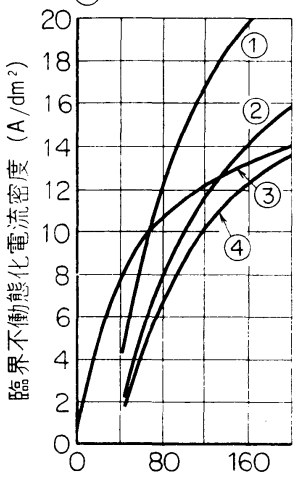

全水酸化+トリウム $(\mathrm{g} / \mathrm{l})$

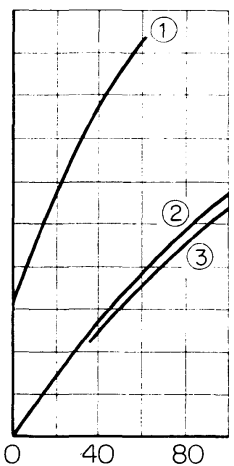

(2) 0

(3) 32

(3) 0

80

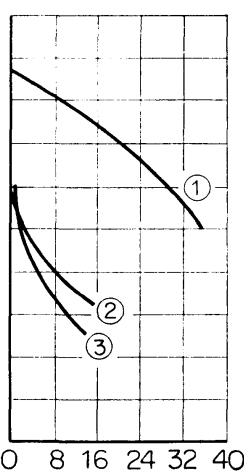

严鎦 $(\mathrm{g} / \mathrm{l})$

第 3 図各種浴組成による臨界不働態電流密度

$\mathrm{Zn}(\mathrm{g} / \mathrm{l}) \quad \mathrm{NaCN}(\mathrm{g} / \mathrm{l})$

(1) $32 \quad 98$

(2) $8 \quad 9.8$

(3) 0

(4) $8 \quad 0$

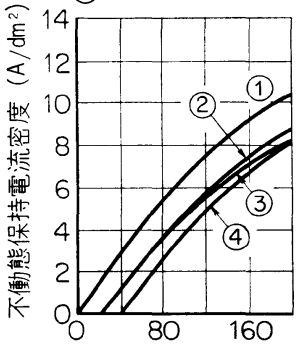

全水酸化ナトリウム $(\mathrm{g} / \mathrm{l})$
$\mathrm{Zn}(\mathrm{g} / \mathrm{l})$ 全 $\mathrm{NaOH}(\mathrm{g} / \mathrm{l}) \quad \mathrm{NaCN}(\mathrm{g} / \mathrm{l})$ 全 $\mathrm{NaOH}(\mathrm{g} / \mathrm{l})$

(1) 8

(2) 0

(3) 32

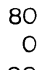

80

(1) 98

(3) 0

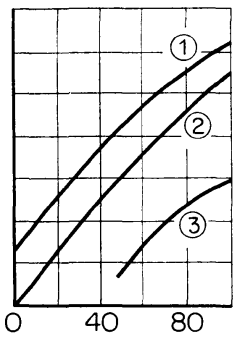

シアン化ナトリウム ( $/ l$ )

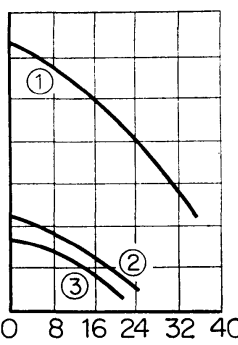

垔鋥 $(\mathrm{g} / \mathrm{l})$

第4図各種浴組成における不働態保持電流密度（最高）

同様の分極曲線が得られる。

一般に，アルカリ性亜鉛メッキ浴における亜鉛の自然 電極単位はー1.5 V, 臨界不働態化電位はー $1.3 \mathrm{~V}$, Flade 電位はー1.1 V, そして酸素発生の電位は1.5V付 近であり，浴組成で大きく変化しない。しかしながら， 電流は浴組成により大きく変化する。これは，第 2 図か らも明らかであるが，第 3 図と第 4 図に各種浴組成に拉 ける臨界不働態化電流と不働態化保持電流の最高電流密 度をプロットした。すなわち，これらより明らかなよら に, 亜鉛陽極の臨界不働態化電流密度と不働態化保持電 流は, メッキ浴中の水酸化ナトリウムとシアン化ナトリ ウム濃度とともに大きくなり，亜鉛濃度の増加により減 少することがわかる。

亜鉛陽極の表面は, 臨界不働態化電位までは金属色を 呈しているが，それ以後の Flade電位まででは白色の皮 膜が生成し, Flade 電位以後の不動態化保持電位ではカ

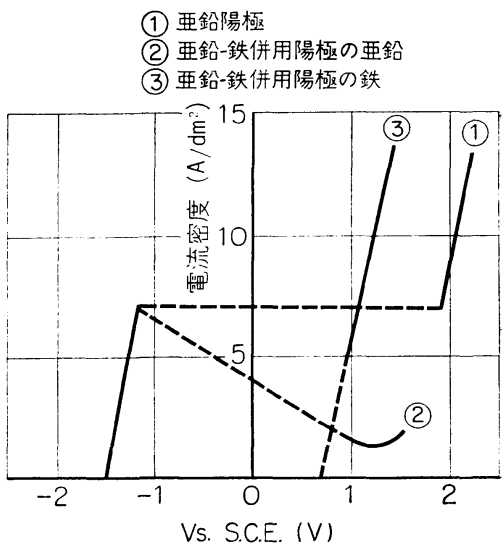

第 5 図 ジンケート浴での定電流電解 による分桠

ッ色〜黒カッ色の皮膜が生成し, 酸素発生の 電位においては黒色皮膜となる。この現象 は，浴中のシアン化ナトリウムと水酸化ナト リウムの濃度が低く，また，亜鉛濃度が高い ほど著しい。

鉄陽極の自然電極電位は飽和甘コウ電極を 規準として約-0.7vであり，分極しても活性 化溶解電流および不働態化保持電流は亜鉛陽 極に比べて非常に微少であり，0.6 V 付近で はじめて酸素を発生して電流が流れる。この 電位および電流は浴組成を変化してもほとん ぞ変化は認められない。

亜鉛と鉄の併用電極に拈いては, 初期の電 位は亜鉛の自然電極電位を示し，電位の上昇 とともに亜鉛単独と同様の臨界不働態化電

流， Flade 電位および不働態化保持電流を示すが，鉄 の酸素発生の電位の $0.6 \mathrm{~V}$ 付近にいたり, 鉄陽極から酸 素を発生する。さらに電位を上昇せしめても鉄陽極から 盛んに酸素を発生するのみで, 亜鉛の酸素電位には至 りにくい。すなわち, 业鉛, 鉄併用陽極の電流電位曲線 は, 亜鉛と鉄のそれぞれの単独極の電流一電位曲線を幾 何学的に合成したものと同一である。

\section{3-2 定電流電解による電流一電位曲線}

定電流電解に打ける代表的な電流一電位曲線は第 5 図 に示したよらになる。

亜鉛陽極に扣いては, 自然電極電位から臨界不働態化 電位までは定電位電解と同様の挙動を示すが，この臨界 不働態化電流に達すると覀鉛の表面は黒カッ色の皮膜で おおわれ, 急激に酸素発生の電位に達し, 盛んに酸素ガ スを発生する。すなわち, 定電流電解では定電位電解で みられたよらなFlade 電位および不働態化保持電流は観 
$\mathrm{Zn}(\mathrm{g} / \mathrm{l}) \mathrm{NaCN}(\mathrm{g} / \mathrm{l})$ 全 $\mathrm{NaOH}(\mathrm{g} / \mathrm{l})$

(1) $32 \quad 98 \quad 80$

(2) $8 \quad 9.8 \quad 80$

(3) $10 \quad 80$

(4) $10 \quad 0 \quad 120$

(5) $10 \quad 0 \quad 200$

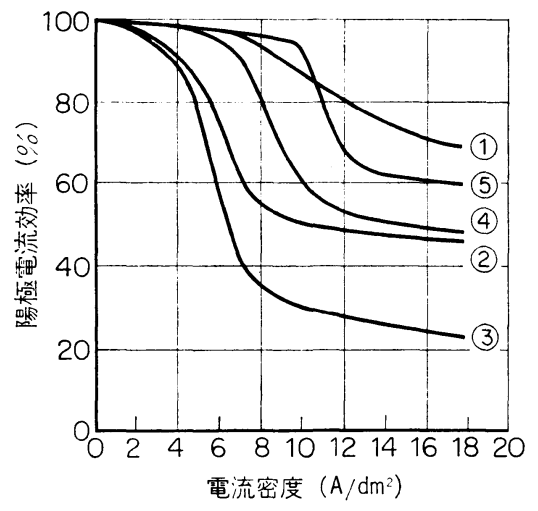

第 6 図要鉛の陽極電流効率

察されない。

鉄単独極に打いても同様であり， $-0.7 \mathrm{~V}$ の自然電極 電位より電解と同時に急激に酸素発生の電位に至り, 酸 素を発生しながら電流が流れる。

亜鉛と鉄を併用した場合には, 初期は亜鉛単独と同様 の挙動を示し, 亜鉛の臨界不働態化電流に至ると急激に 電位は変化し, 鉄の酸素発生の電位に達し, 鉄陽極にも 電流が流れる。この場合, 亜鉛に流れていた電流は低下 し, 両極に流れた電流の合計が亜鉛の臨界不働態化電流 と同様になる。さらに，電流を増加すれば，鉄陽極のみ 飞多くの電流が流れ, 亜鉛陽極に流れる電流はやや低下 する傾向にある。すなわち，この場合の亜鉛陽極は，鉄 の酸素発生の電位である $0.6 \mathrm{~V}$ 以上付近の電位で定電位 電解されていることになり, 亜鉛陽極には定電位電解に おける不働態化保持電流が流れている。

\section{3-3 亜鉛陽極の電流効率之皮膜の生成}

第 6 図は代表的な浴組成での亜鉛の陽極電流効率の变 化を示している。この図からも明らかなよらに, 低電流 密度に沶いてはその電流効率は $100 \%$ である。水酸化ナ トリウム拉よびシアン化ナトリウム濃度が濃いほど高い 電流密度でも電流効率は大さいことがわかる。これは, 水酸化ナトリウムおよびシアン化ナトリウム濃度の増加 によって, 臨界不働態化電流密度が高くなるといら上述 の結果とよく一致している。また, それ以後の電流効率 の低下も水酸化ナトリウム濃度の濃いほど少ないことが わかる。これらは，すでに酸素発生の条件ではあるが， 不働態化保持電流に相当していると考えられる。

定電位電解による各電位での電流効率は第 7 図に示し たよらになる。活性化範囲においては, いずれの浴にお
(1) シシンケート浴

(2) 低シアン亚鉛浴

(3) 高シアン亜鉛浴

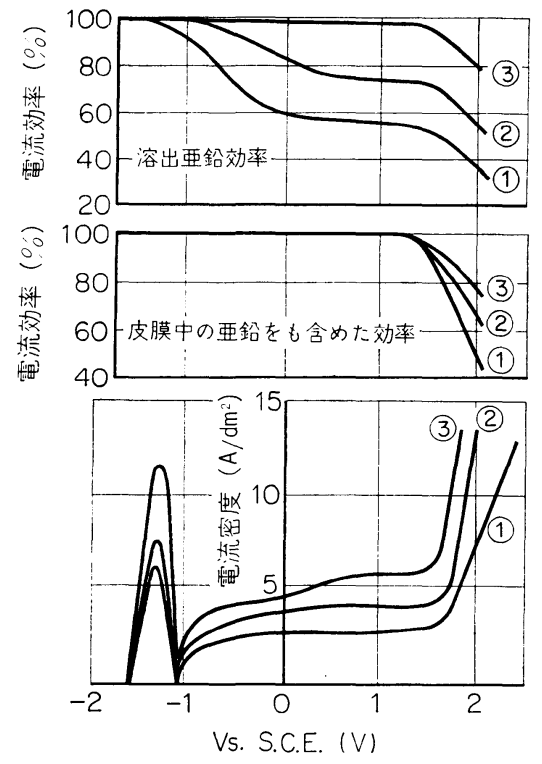

第7図定電位電解での亜鉛の電流効率

いても皮膜の生成はみられず，その電流効率は $100 \%$ で ある。臨界不働態電位以後に拈いては, 亜鉛の溶解効率 は低下する。この場合の亜鉛の溶解効率とは, 前にも述 べたように, 実験前後の試料の重量差より求めたもので あり, 皮膜中の亜鉛を無視したメッキ液中に溶解した亜 鉛の電流効率である。シアン化亜鉛メッキ浴では, 不働 態化保持電流に拈いても, ほぼ $100 \%$ に近い電流効率を 示すが, 低シアン浴では, Flade 電位以後で減少しはじ めて約 $70 \%$, ジンケート浴では臨界不働態電位以後より 減少し, 不働態化保持電流では約55\%の電流効率となっ ている。いずれの浴に拈いても酸素発生の電位以上で は, さらに電流効率は低下しているが，これは当然のこ とである。

臨界不働態化電位以上 Flade電位までに発生した皮膜 は白色であるが，この皮膜中の亜鉛の含有量は分析の結 果では約63\%である。また, Flade 電位以後の不働態化 保持電位および酸素発生の電位において発生したカッ色

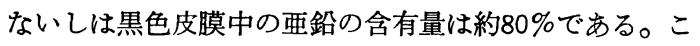
れらの皮膜中の亜鉛をも含めた亜鉛の電流効率は, 第 7 図に示したよらに，いずれの浴においても100\%となる。

\section{3一4 アルカリ性亜鉛メッキ液における陽㮒亜鉛の溶} 解

アルカリ性亜鉛メッキ液における陽極の溶解は活性化 範囲においては皮膜は生成していないので，亜鉛は，

$\mathrm{Zn}+\mathrm{nOH}-\longrightarrow \mathrm{Zn}(\mathrm{OH})_{\mathrm{n}}^{(\mathrm{n}-2)-}+2 \mathrm{e} \cdots \cdots \cdots \cdots \cdots \cdots(1)$ 
$\mathrm{Zn}+4 \mathrm{CN}^{-} \longrightarrow \mathrm{Zn}(\mathrm{CN})_{4}^{2-}+2 \mathrm{e} \cdots \cdots \cdots \cdots \cdots \cdots \cdots(2)$

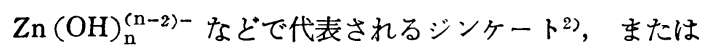
シフン錯塩として溶解していることは明らかでありこ の溶解の最高電流密度, すなわち, 不働態化電流密度は 水酸化ナトリウムとシアン化ナトリウム濃度とともに増 加し，亜鉛濃度の増加とともに減少している。

臨界不働態電位から Flade電位の間においては, 高シ アン浴や低シアン浴のようなシアン化物を含んだメッキ 浴では皮膜の生成は汪とんど見受けられず，また，多少 発生しても，電解を中止し溶液中より引きあげる間に溶 解してしまう。ジンケート浴では, 白色ないし灰白色の 皮膜が生成し, この皮膜中の亜鉛の含有量は前にも述べ たように63\%前後であることから，これは $\mathrm{Zn}(\mathrm{OH})_{2}$ の 組成に相当するので, この間の巠鉛の溶解反応は,

$\mathrm{Zn}+2 \mathrm{OH}^{-} \longrightarrow \mathrm{Zn}(\mathrm{OH})_{2}^{2-} \longrightarrow \mathrm{Zn}(\mathrm{OH})_{2}+2 \mathrm{e} \cdots \cdots \cdot(3)$ ではないかと考えられる。

この電位に扣ける電解に打いては，電流は大きく振動 し, 皮膜の生成と溶解がくり返されていることがわか る。また，この皮膜はシアン化ナトリウムにはよく溶解 するので，シアン化ナトリウムを含んだメッキ浴では皮 膜は生成しにくいと考兄られる。

不働態化保持電位打よび酸素発生の電位で発生するカ ッ色ないし黒色皮膜中の亜鉛の含有量は80\%前後の值を 示すので，その組成は $\mathrm{ZnO}$ ではないかと考兄られる。 したがって,この間の反応は,

$\mathrm{Zn}+2 \mathrm{OH}^{-} \longrightarrow \mathrm{Zn}(\mathrm{OH})_{2}^{2-} \longrightarrow \mathrm{ZnO}+\mathrm{H}_{2} \mathrm{O}+2 \mathrm{e} \cdots(4)$ が考えられる。この場合, 一定の電位で電解していると 電流はしだいに減少するので, 皮膜は電流量の增加にし たがって厚くなっていることがうかがわれる。この皮膜 は水酸化ナトリウム溶液よりもシアン化ナトリウム溶液 に溶けやすく，また，酸化亜鉛は水酸化ナトリウムの濃 度が濃いほどジンケートとして溶解しやすい2)ので，こ れらの条件における不働態化保持電流は大きくなると考 えられる。

一般に, Flade 電位以上の不働態範囲に打ける金属の 溶解は, 不働態酸化皮膜を通って一定の速度で溶解す る。電位を增加しても皮膜の厚岂皮膜内の電場を一定 に保つように増加するので，その溶解速度は汪とんど一 定である。また, この不働態化電流が一定であるのは, 化学的に溶解する不働態皮膜の置き換えられる速度が一 定であるためであるともいわれている7゙。

この実験に打いては，皮膜中の亜鉛の含有量はEDTA による分析によって求めて考察したが，一般に不働態皮 膜酸化物は多くの場合, 化学量論的な組成から少しずれ ている8)といわれているので，さらに詳しく検討してみ る必要があることは事実である。

酸素発生電位以上の過不働態範囲では，(4)の反応のほ
かに OHーおよび $\mathrm{CN}$-の分解反応が起こっていることは もちろんのことである。

\section{3-5 アルカリ性亜鉛メッキ浴における陽極の使用方 法と浴管理}

現在一般に使用されているシアン化亜鉛メッキ浴はお もに陰極，すなわち，メッキに重点が抢かれた浴組成で ある。普通使用されているシアン化亜鉛メッキ浴では, 陰極の電流効率よりも陽極の電流効率の方がよく, 加兄 るに亜鉛陽極は電流を流さなくても化学的に溶解される ので, メッキ作業中のメッキ液のくみ出しを考慮しても 浴中の亜鉛濃度は増加する傾向にある。したがって，こ れを陽極的に考兵た場合, 上述の実験結果が 示すよう に, 水酸化ナトリウムやシアン化ナトリウム濃度を減少 させるか，または，亜鉛濃度の増加が考えられるが，こ れでは良好なメッキは得られない。それで，従来までは 浴中の亜鉛濃度を一定に保つ方法として，メッキ液の一 部棄却やくみ出し量をあまり気にしないというような方 法で管理されてきたが，これでは排水処理に秥いても， 経済的にも問題が多い。その他の方法としては, 亜鉛陽 極の量を少なくして，陽極の電流密度を高くして作業す る方法もあるが，これは第 6 図からも明らかなように相 当の高電流密度で使用しなければならず，この方法では メッキ厚サのバラッキが問題となる。したがって，不溶 性陽極である鉄陽極と亜鉛陽極の併用が行なわれる。し かし，ここで注意しなければならないことはその使用方 法である。いま，亜鉛と鉄陽極を併用した場合，もし， 鉄陽極から酸素が発生していないよらな条件で使用する ならば，上述の実験結果が示すよらに，鉄陽極はただ単 にメッキ液中に吊り下げられているだけで，まったく陽 極としては作用していないといらことになる。しかし， この方法はアルカリ性亜鉛メッキ浴において, 鉄のブス バーやフックなどを浴中に沈めて亜鉛陽極との電気的接 触をよくするための方法や，鉄製のバスケット内に亜鉛 陽極を入れて使用する場合のような，鉄はただ単に電導 的な役目をさせる場合にはこの方法は望ましい。このよ らな条件に拀いても鉄はいくぶん溶解するであろらけれ ぞもシアン化ナトリウムの分解は起こらない。

浴中の亜鉛濃度およびシアン化ナトリウム濃度を減少

第 2 表 各浴組成汇拈ける亜鉛・鉄両陽極を併用乙 た場合の電流密度，電位と亜鉛の電流効率

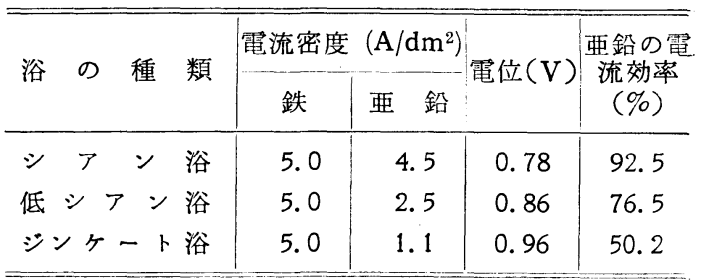


させることを目的とする場合には，鉄陽極から酸素が発 生している条件で使用しなければならない。この場合, 亜鉛は定電位電解に打ける不働能化保持電流で電解され ている。ここで注意しなければならないことは前にも述 べたように, 不働能化保持電流密度は浴組成により変化 し，また，鉄は鉄素発生電位での電流の立ち上がりが速 いので，亜鉛陽極と鉄陽極に流れる電流密度を同一にす ることは亜鉛と鉄の面積比を含めて非常に困難なことで あるといわなければならない。第 2 表は，各標準浴組成 のアルカリ性亜鉛メッキ浴で同一表面積の亜鉛と鉄陽極 を併用し，鉄陽極の電流密度を $5 \mathrm{~A} / \mathrm{dm}^{2}$ と一定にした場 合の亜鉛陽極の電流密度とその電位および亜鉛の陽極電 流効率を示している。このような亜鉛と鉄併用陽極に打 いて，両極の電流密度を同一にしょうとすれば，合金メ ッキに打汓る分離陽極の使用方法のよらな別回路による 各陽極の使用方法を採用しなければならないだろらの。

低シアン亜鉛メッキ浴に批いては, シアン化亜鉛メッ キ浴よりも臨界不働態化電流密度, 不働態化保持電流中 陽極電流効率が急激に低下する電流密度, 酸素発生範囲 での電流効率は低い。したがって，浴中の亜鉛濃度の増 加はシアン化亜鉛メッキ浴の場合より少ないようであ り，この点有利であると考えられる。

水酸化ナトリウム濃度の低いジンケート浴では，すぐ に陽極要鉛は不働態化してしまう。本実験に使用したジ ンヶート浴の基本浴組成に执いてもその傾向にある。一 般に安定なジンケート溶液とは, $2 \mathrm{nZnO} \cdot \alpha \mathrm{n} 2 / 3 \mathrm{Na}_{2} \mathrm{O}$ 亿抒 いて $\boldsymbol{\alpha}$ が10以上の組成であるといわ机ている22。光沢ジ ンケート浴の組成としては，亜鉛 $7.5 \mathrm{~g} / l$, 水酸化ナトリ

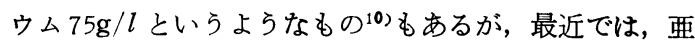
鉛 $13 \mathrm{~g} / l$, 水酸化ナトリウム $140 \mathrm{~g} / l^{11) \sim 13)}$ 中亜鉛 $15 \mathrm{~g} / l$, 水酸化ナトリウム $180 \mathrm{~g} / l^{14)}$ などの比較的高濃度浴が用 いられるよらになっていている。これは，浴管理上重要 なことである。水酸化ナトリウム濃度が $110 \mathrm{~g} / l$ 以下に なると，陽極亜鉛の溶解はきわめて悪くなるといわれて

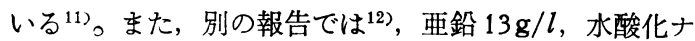
トリウム $140 \mathrm{~g} / \mathrm{l}$ の光沢ジンケート浴で, 低シアンおよ び中シアンないし高シアン浴と比較実験を行なった結 果，亜鉛陽極はジンケート浴では40～50\%，低シアン浴 では10〜20\%分極したのに対して，中ないし高シアン浴 では分極はほとんどなかったといわれている。

低シアン浴では，この実験に使用した浴組成で，ほぼ バランスがとれているよらであるが，これは作業条件に よっても異なるので，もし，亜鉛濃度が増加する傾向に あるならば，水酸化ナトリウム濃度を減少し，逆に亜鉛 が減少する場合にはその濃度を増すべきである。ジンヶ 一ト浴についても同様のことがいいらるが，浴組成の変 化は陰極の電流効率にも大きく関係する ${ }^{13}$ ので，光沢ジ
ンケート浴の浴組成は, 能率よく光沢亜鉛メッキが得ら れる条件と浴組成を一定に保てるような陽極の条件の両 方を考慮したものでなくてはならない。

\section{4. おわりに}

各種アルカリ性亜鉛メッキ液について，亜鉛および鉄 とこれらを併用した場合の陽極の挙動について検討し次 のよらな結果を得た。

1）アルカリ性亜鉛メッキ浴に批ける亜鉛陽極の分極 は, 浴中の水酸化ナトリウム, シアン化ナトリウム濃度 の濃いほど，また，亜鉛濃度がうすいほど小さい。

2）活性化範囲においては，亜鉛陽極は $100 \%$ の電流 効率で溶解するが，臨界不働態化電位から Flade電位ま ででは $\mathrm{Zn}(\mathrm{OH})_{2}$ に相当する皮膜が生成し，それ以後の 不働態化保持電位ではZnOに相当する皮膜が生成する。 しかし、これらの皮膜中の亜鉛の含有量をも含めれば， その電流効率は100\%となる。

3）亜鉛と鉄とを併用した場合には，最初は亜鉛の陽 極挙動を示すが，その後は鉄の酸素発生の電位にいたり 鉄陽極から酸素を発生し，亜鉛は不働態化電位で電解さ れている。

4）以上のことがらは，アルカリ性亜鉛メッキを使用 する場合の陽極とメッキ液の管理に重要である。

最後に, 本研究は当館の公害対策研究としてのシアン を使用しない光沢亜鉛メッキ液の開発研究の一環として 行なったものであることを申しそえておく。

$$
\text { (1971-4-19 受理) }
$$

(昭和45年11月, 本協会第42回学術講演大会にて発表)

\section{文献}

1) 川崎, 水本, 電気メッキ研究会講演資料 (昭 44 . 6. 27)

2) 小西ら, 本誌, 20, 232 (1969)

3) 小西5, 本誌, 20, 315 (1969)

4) M. N. Hull ら, J. Electrochemical Soc., 117, 192 (1970)

5) 加納 5 , 本誌, 21，60 (1970)

6 ）前田, “電極の化学” p. 335 (1961，技報堂)

7 ) J. M. West (岡本ら訳) “電析之腐食” p. 78 (1968, 産業図書)

8 ）前田, “電極の化学” p. 238 (1961，技報堂）

9) A. Brenner, "Electrodeposition of Alloys, Vol I, p. 64 (Academic Press)

10) Du Tone Chemical Co. Inc., Du Zinc NCN

11) Rea Ronal Inc., Zin-Al

12) R. R. Bair, Plating, 57, 349 (1970)

13) R. Ostrow, Plating 57, 354 (1970)

14) Schering A. G., CFK-W, CF-GT 